研 究

\author{
薄肉・中空品の MIM インプロセス接合 \\ 三浦 秀士放 1 , 矢野 健文放 2 , 松田 光弘 \\ 41 熊本大学工学部知能生産システム工学科, ₹ 860-8555 熊本市黒髪 2-39-1. \\ 的熊本大学大学院自然科学研究科, $=860-8555$ 熊本市黒髪 2-39-1.
}

\title{
MIM In-process Joining of Thin and Hollow Parts
}

\author{
Hideshi Miura ${ }^{\text {t } 1}$, Takefumi Yano ${ }^{\text {tr } 2}$ and Mitsuhiro Matsuda ${ }^{\star 1}$ \\ ${ }^{1}$ Dept. Mech. Eng. \& Materials Sci., Kumamoto University, 2-39-1 Kurokami, Kumamoto 860-8555. \\ ${ }^{2}$ Graduate School, Kumamoto University, 2-39-1 Kurokami, Kumamoto 860-8555.
}

Received July 16, 2001

\begin{abstract}
SYNOPSIS
MIM process is hoped to be an advanced powder processing technique for near net shape forming the high density, high performance, and complicated parts. However, there still remains the issue of limitation in the shape and volume of MIM compacts because of using the die.

In this study, as one of new approaches to improve the above problems in MIM process, MIM in-process joining of thin and hollow parts by using the exuded wax during solvent debinding step has been attempted to produce larger, more complicated and functional parts by combination of the same or different materials such as martensitic (SUS420J1) and austenitic (SUS304L) stainless steels.
\end{abstract}

KEY WORDS

metal injection molding, in-process joining, thin and hollow parts, exuded wax, solvent debinding

\section{1 緒 言}

金属粉末射出成形(MIM) プロセスによれば，旧来の金型プ レス成形による粉末冶金法では得られない高密度で 3 次元的 に複雑な形状の部品をニアネットシェイプで作製することが できるが1)，本プロセスを用いてMIM製品のさらなる大型化・ 複雑化に加え，異種材料の組み合わせによっては多機能化に も対応しうるMIMインプロセス接合の応用展開も期待されて

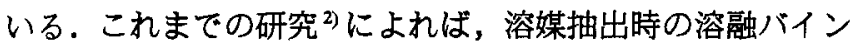
ダを利用することで同種，異種材ともに加圧力を必要とする ことなく，接合可能なことがわかっている.

本研究では磁性を呈するマルテンサイト系ステンレス鋼 (SUS420J1)粉末と, 非磁性のオーステナイト系ステンレス鋼 (SUS304L) 粉末を用いて，従来の単純形状部品の組み合わせ でなく,より MIMの特長を生かすという実践的観点よりリン グ形状をした薄肉かつ中空品である成形体(Fig.1)を作製し， それらの脱脂，焼結特性ならびに 3 ピース品の接合特性につ いて調查，検討した。

\section{2 実験方法}

原料粉末としては，それそれの平均粒径が $13.24 \mu \mathrm{m}, 11.47 \mu \mathrm{m}$
のガスアトマイス・ステンレス鋼 SUS420J1 と SUS304Lの両 粉末を使用した. 両粉末の化学成分を Table 1 に示す. バインダ にはパラフィンワックス 69 mass\%，ポリプロピレン 20 mass\%， カルナウバワックス 10 mass\%およびステアリン酸 1 mass\% か ら成るワックス系バインダを使用した、上記の粉末とバイン ダを体積比で $60: 0$ となるように配合し，423 K, 3.6ksで加熱 混練した後，横型スクリュ一射出成形機を用いて薄肉・中空 品である3つの重ね合わせ用成形体を作製した．Fig.1に，成 形体端部に 45 度の角度をつけて重ね合わせた, 種々の組み合 わせの成形体を示す，ついで，前報2)の結果よりへプタン溶 剤を使用してバインダ中の主にワックス成分を $358 \mathrm{~K}$ 抽出脱脂した後, 加熱脱脂・焼結を同一炉内で水素雾囲気中， $1573 \mathrm{~K} て ゙ 3.6 \mathrm{ks}$ 施した. 焼結後の試料は組織観察, 引張試験， EPMA 元素分析等に供し，接合特性を総合的に評価した。

\section{3 実験結果および考察}

まず，単に重ね合わせた試料の焼結後の接合体の外観写真 をFig.2に示す. 本実験に使用した試料は薄肉・中空品であっ たために，単なる 3 ビースを組み合すせて焼結したたけでは 接合はうまくゆかず，健全な焼結体を得ることはできなかっ 
た. そこでFig.3にも示すように, 試料のずれを生じさせない ようにアルミナのブロック体に試料より大きめの穴をくりぬ いて，そこに試料を入れさらにアルミナ粉末で包み込み，脱 脂・焼結を施すという工夫を行った. 得られた接合体の外観
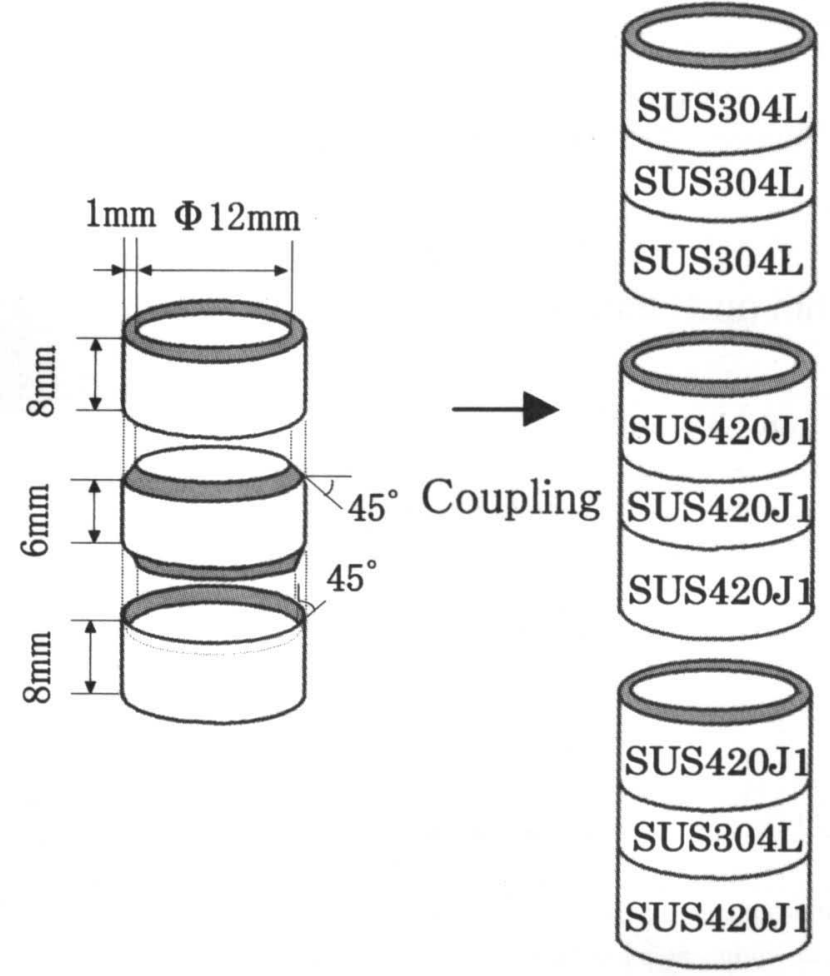

Fig.1 Schematic illustration of the coupling.

Table 1 Chemical compositions of the powders used in this study.

\begin{tabular}{|c|c|c|c|c|c|c|c|}
\hline \multirow{2}{*}{ Powder } & \multicolumn{6}{|c|}{ Chemical composition (mass\%) } \\
\cline { 2 - 8 } & $\mathrm{Cr}$ & $\mathrm{Ni}$ & $\mathrm{Si}$ & $\mathrm{Mn}$ & $\mathrm{C}$ & $\mathrm{O}$ & $\mathrm{Fe}$ \\
\hline SUS304L & 19.6 & 11.9 & 0.67 & 0.09 & 0.023 & 0.067 & bal. \\
\hline SUS420J1 & 12.7 & - & 0.41 & 0.13 & 0.194 & 0.074 & bal. \\
\hline
\end{tabular}

写真を Fig.4に示す. 目視した限りでは未接合部は観察され ず，良好に接合しており，アルミナ粉末による外部からの拘 束とウィキング効果によるワックス成分の抽出が効を奏した ものと思われる. Fig.5に接合部の顕微鏡写真を示す. 同種材 同士では界面の判別もつかないほど良好に接合しており，両 試料とも高密度で気孔は独立球状の気孔を呈していた.ただ， SUS420J1 材 (相対密度: 96.2\%) に比へ SUS304L材 (相対密度: 93.5\%)の方が密度は若干低い值を示した. このことは, ステ ンレス鋼焼結材の緻密化挙動に関する報告3,4)参照すれば, $\gamma$ 相域で焼結が進行するオーステナイト系ステンレス鋼に比較 して，マルテンサイト系の方は拡散が容易で緻密化しやすい $\alpha$ 相域で実際の焼結が進行した可能性を示唆している.なお, 異種材同士でも界面において粗大な気孔や亀裂などは観察さ れず，極めて良好に接合していた.

そこで次に，引張試験による接合強度を調べた. Fig.6に同 種，異種材の接合体ならびに SUS420J1, SUS304L 焼結材の単 体の引張試験結果を示す. なお, 本試料のような薄肉・中空 品の接合強度の直接評価は難しいため, 試験はリング形状と 同じ 45 度の接合面にて接合した引張試験片で行った.これよ
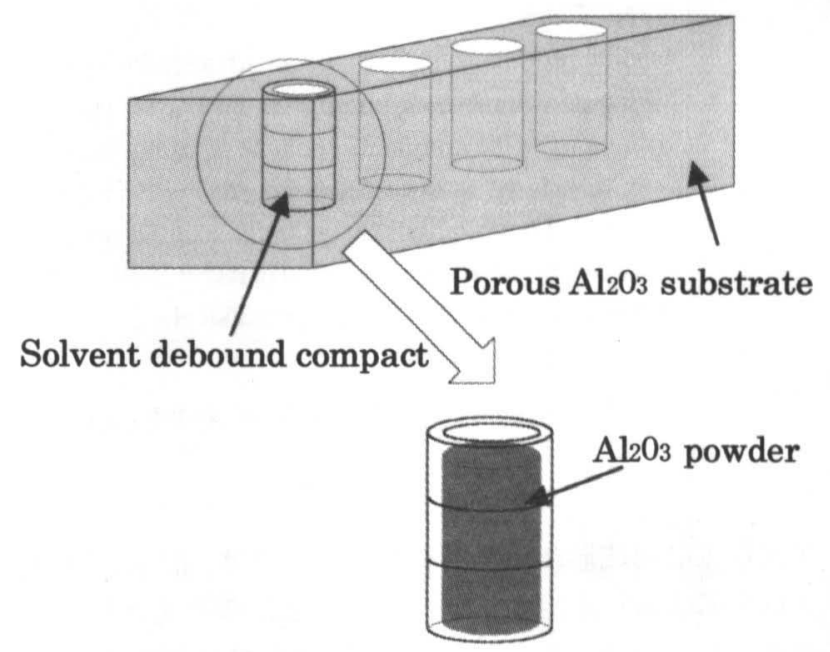

Fig.3 Schematic illustration of the porous $\mathrm{Al}_{2} \mathrm{O}_{3}$ substrate.

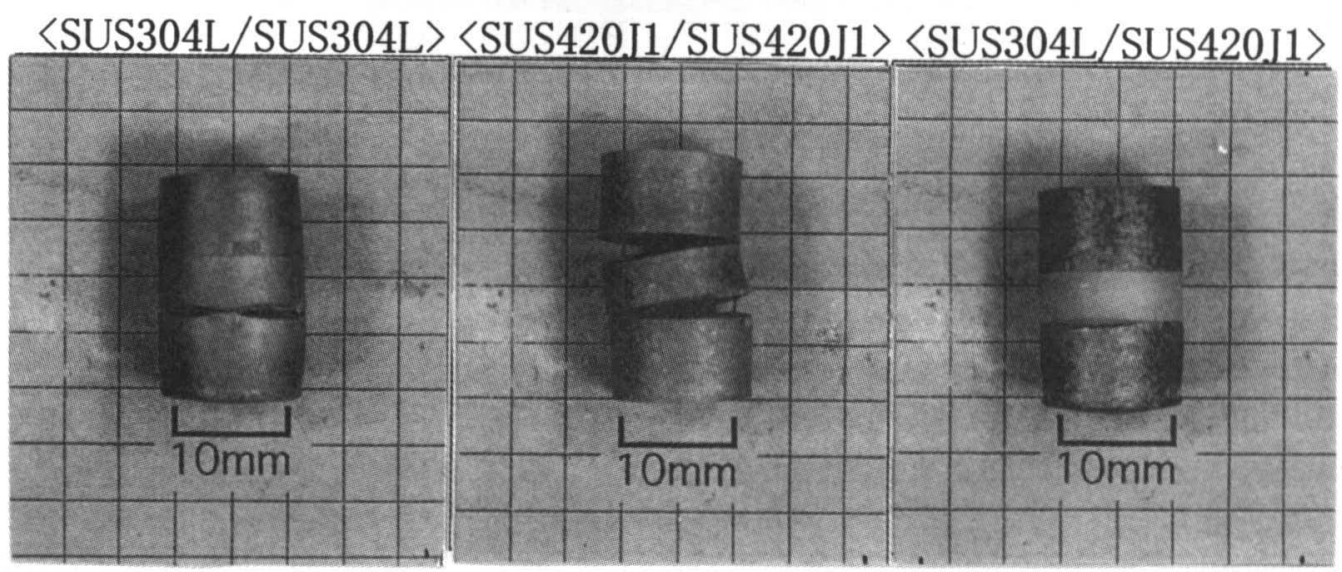

Fig.2 Aspects of various couples sintered at $1573 \mathrm{~K}$ in $\mathrm{H}_{2}$. 


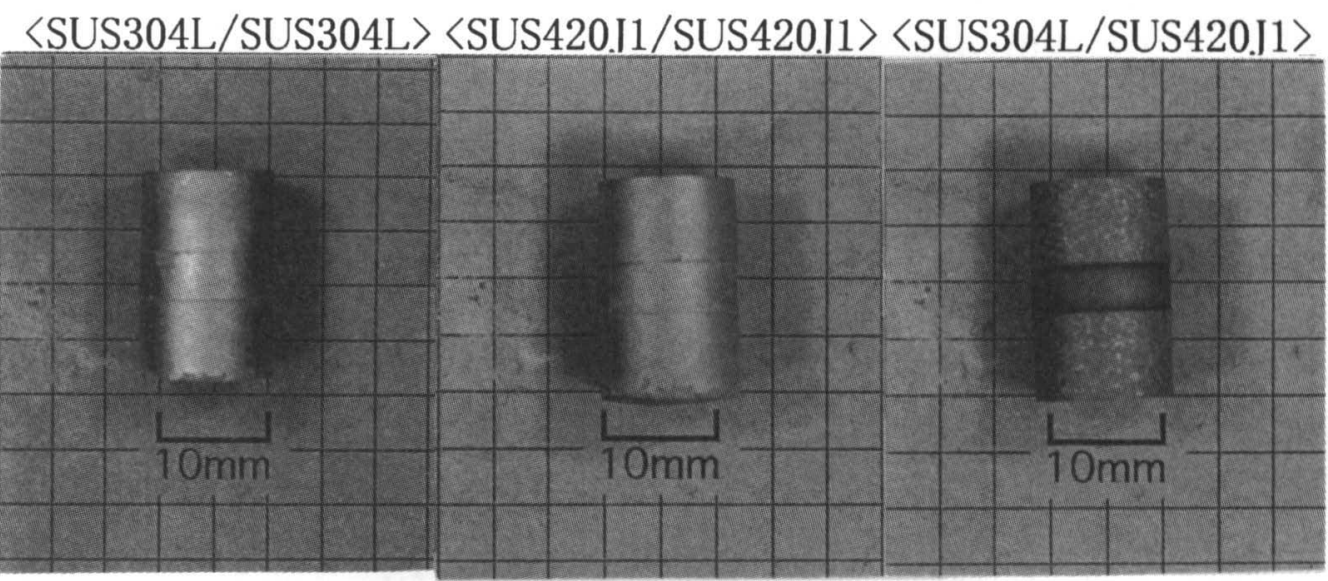

Fig.4 Aspects of various couples sintered at $1573 \mathrm{~K}$ in $\mathrm{H}_{2}$.

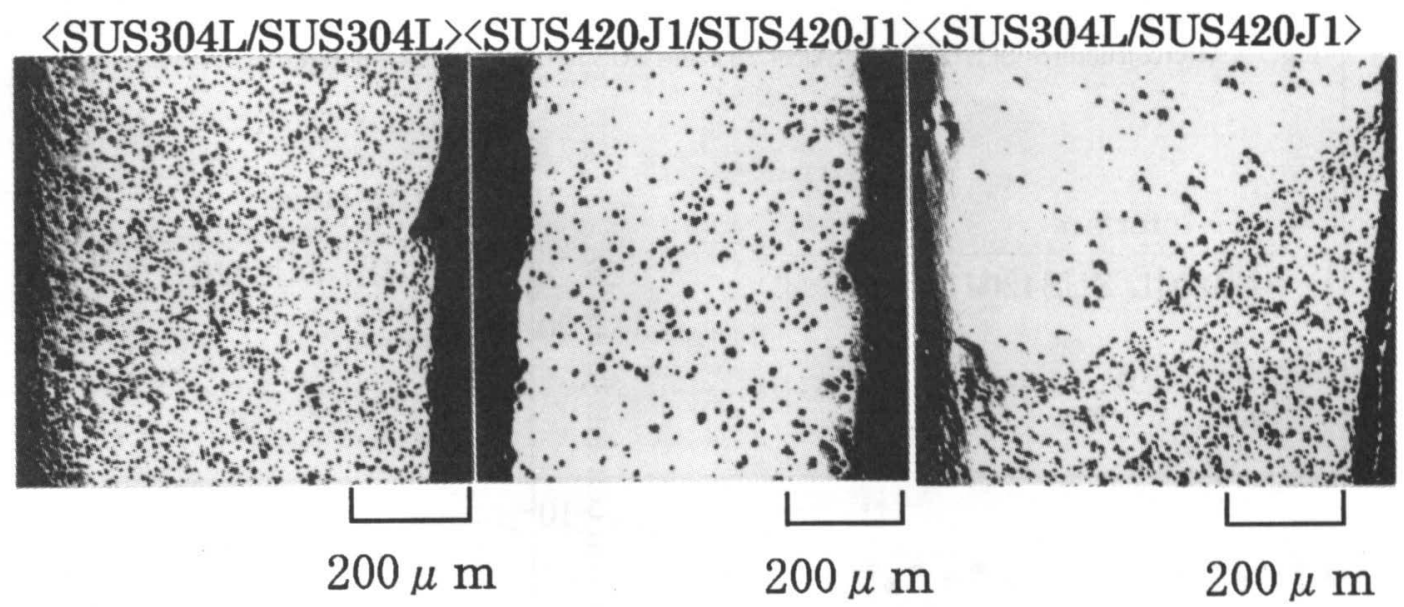

Fig.5 Microstructures of the joined area for sintered SUS304L/SUS304L, SUS420J1/SUS420J1 and SUS304L/SUS420J1 couples.

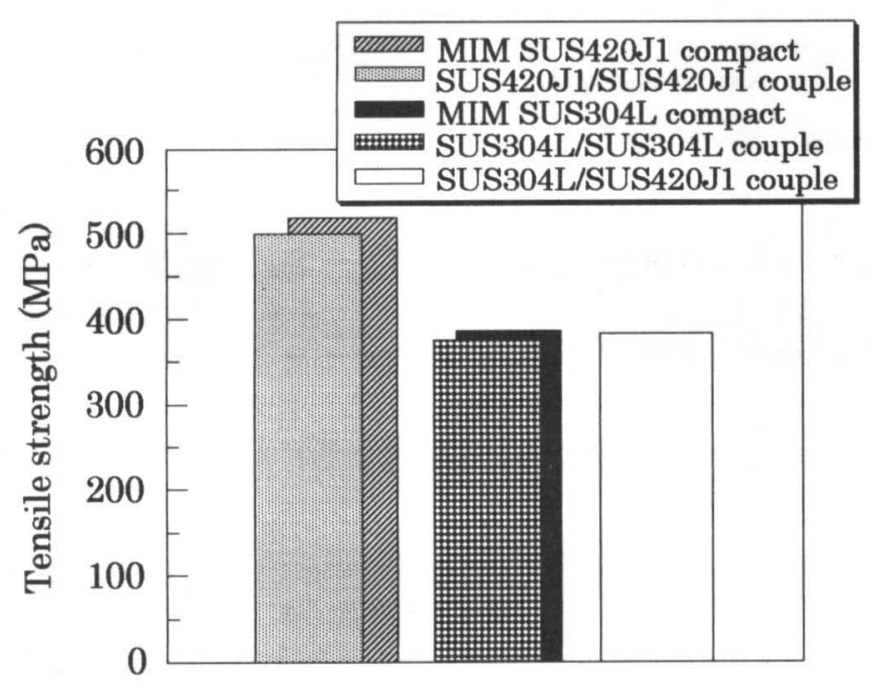

Fig.6 The tensile strength of MIM compacts and various couples sintered at $1573 \mathrm{~K}$ in $\mathrm{H}_{2}$.
り，接合体は焼結単体の強度とほぼ同等の值を示しているこ とから, 十分に一体化していると言える.なお, 今回の実験 では高密度化ならびに不純物の還元という観点から，焼結は 水素雾囲気で行った. そのため, 焼結雾囲気による脱炭等も 考えられることから組織観察も行った. Fig.7にSUS420J1材， SUS304L材の炭素分析結果, 組織写真ならびに両部材の接合 部の組織写真を示す. SUS304Lはオーステナイトを呈してい るが, SUS420J1 材ではもともと粉末中に炭素は $0.2 \mathrm{mass} \%$ ほ ど含まれていたにもかかわらず，焼結後には 0.01 mass\%にま で減少したためフェライトを呈しており, 明らかに水素焼結 による脱炭が生じていた.この脱炭がSUS420J1材に上記の $\alpha$ 相域焼結を生じていたことは容易に知れる.

ところで, 両部材の接合部近傍においてSUS420J1側には両 部材とは異なる組織が観察されたことから, 接合界面近傍の 微小硬度を測定した. その結果を Fig. 8 に示す. 界面近傍の SUS420J1側に存在していた組織には, 基地に対して高硬度な ものが存在していることがわかる. 接合界面近傍のEPMAに 


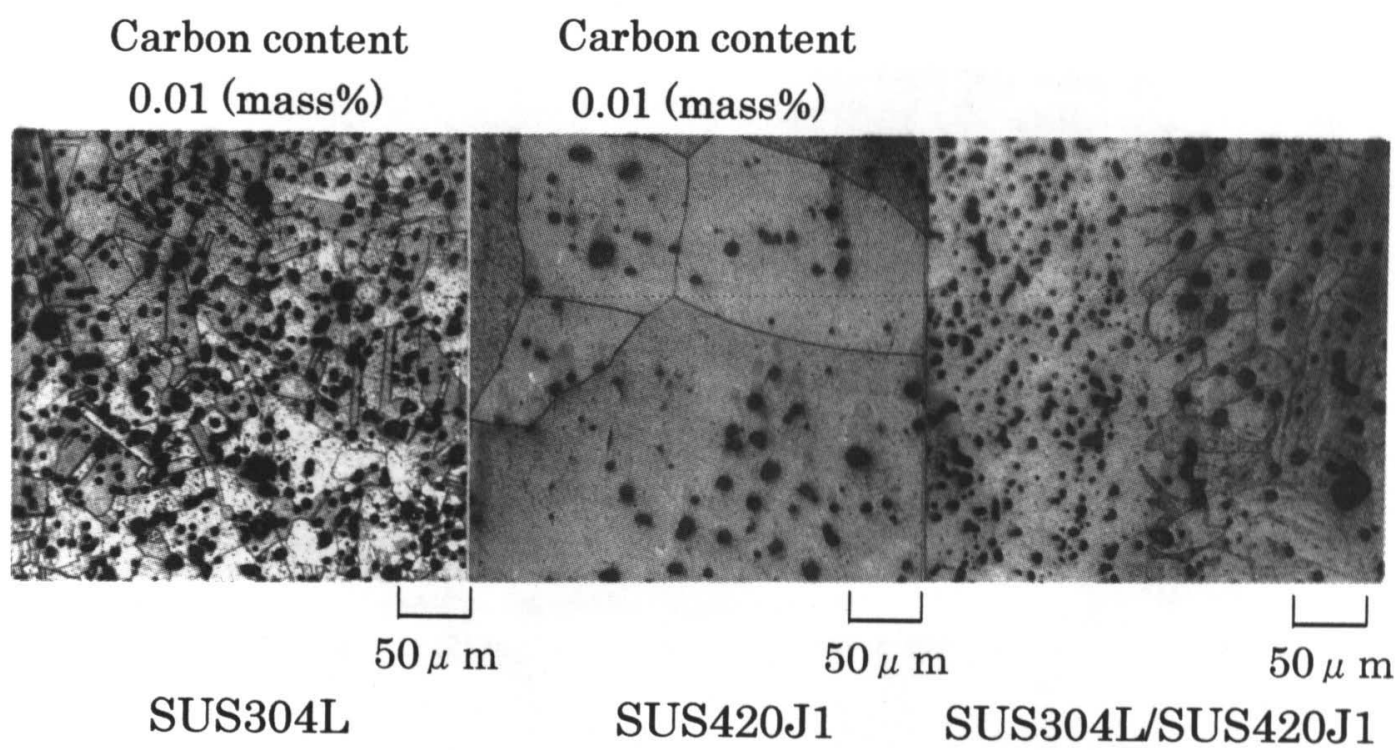

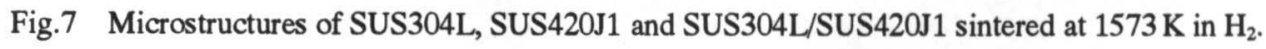

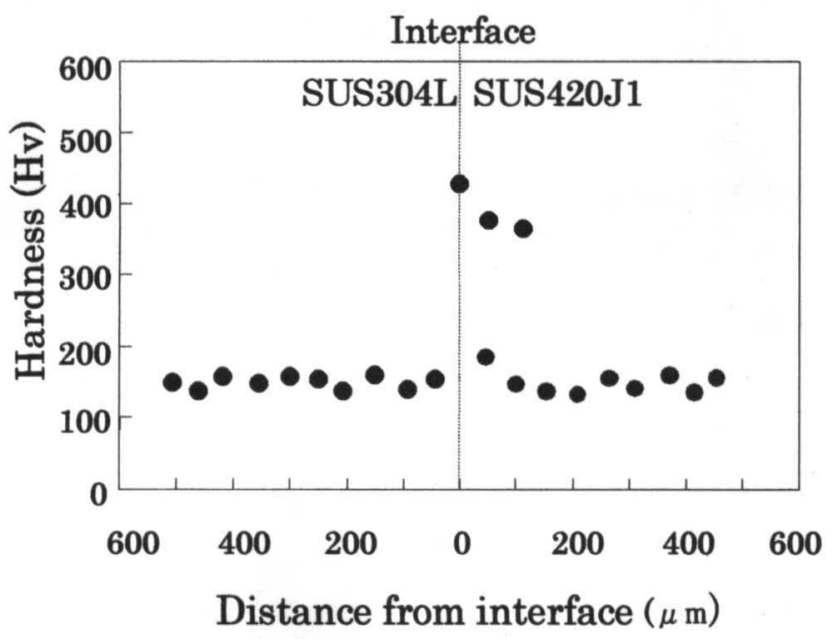

Fig.8 Hardness distributions near the joined area of SUS304L/ SUS420J1 couple sintered at $1573 \mathrm{~K}$ in $\mathrm{H}_{2}$.

よる元素分析結果を Fig.9に示すが, SUS304L 中の Ni が SUS420J1側へと拡散していることがわかる.拡散層における 組織については, $\mathrm{Ni}$ 量と $\mathrm{Cr}$ 量の測定の結果, シェフラーの組 織図 ${ }^{5)}$ からマルテンサイトとフェライトの混合組織であるこ とがわかった.このことは, 本試料のような薄肉・中空部品 においても界面の接合度合が高く, 接合面を通る拡散が活発 に生じていることを証明するものでもある.

\section{4 結言}

マルテンサイト系ステンレス鋼(SUS420J1)粉末とオーステ ナイト系ステンレス鋼 (SUS304L) 粉末を用いて, 薄肉かつ中 空品である成形体を作製し, それらの脱脂, 焼結特性ならび

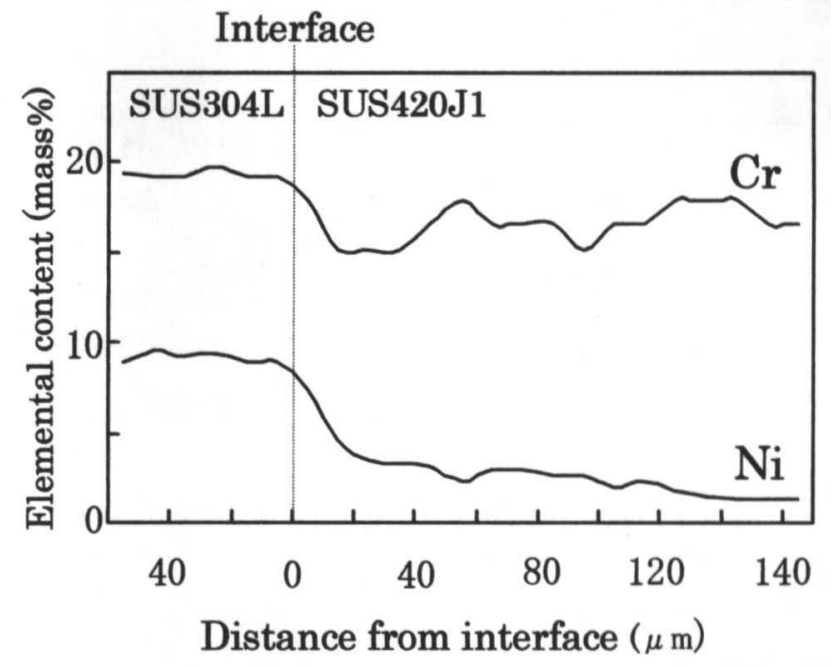

Fig.9 EPMA line analysis of joined area for the SUS304L/ SUS420J1 couple sintered at $1573 \mathrm{~K}$ in $\mathrm{H}_{2}$.

に 3 ピースの接合特性について調查, 検討した結果, 以下の 結論を得た.

(1) 薄肉・中空品の成形体をアルミナ粉末で包み込み, 脱脂・ 焼結を施すことで健全な焼結体を得ることができた.

(2) 同種材料同士の接合体を引張試験したところ, 単体の MIM 材と同等な值が得られ，しかも接合界面の判別もつ かないほど, ほぼ完全に一体化していることがわかった.

(3) SUS304L/SUS420J1の異種材料の組み合わせ接合体におい て, SUS304L側から SUS420J1側へNiがかなり拡散してお り,接合部近傍においてはマルテンサイトおよびフェライ トの混合組織が形成されていることから,接合面を通る拡 散が活発に生じていることがわかった。 
文献

1) 三浦秀士, 高木研: 粉末治金の科学, 内田老鶴专,(1990) 215 .

2) 三浦秀士, 森健太郎: " 新しい MIM 接合プロセスの開発と 応用",粉体および粉末治金, 46(1999)927-932.

3）鎌田政智, 徳永洋一: "マルテンサイト系焼結ステンレス鋼
の緻密化および引張特性に及ぼす炭素量の影響", 粉体およ び粉末冶金, 38(1991)83-87.

4) 武田徹, 田村皓司: "ステンレス鋼圧粉体の焼結に伴う緻密 化について",粉体および粉末冶金, 17(1971)28-36.

5) 日本金属学会編 : 金属データブック, 丸善,(1987)127. 